\section{Original article}

\title{
Seropositivity against HPV 16 capsids: a better marker of past sexual behaviour than presence of HPV DNA
}

\author{
Anne O Olsen, Joakim Dillner, Kirsti Gjøen, Per Magnus
}

Objectives: To assess if seropositivity to human papillomavirus type 16 capsids is a better marker of sexual history than the presence of HPV DNA.

Study design: A population based age stratified random sample of 234 Norwegian women (mean age $32 \cdot 8$ years, range 20-44) was examined for HPV 16 serum antibodies, cervical HPV DNA, cytology and age in relation to sexual behaviour.

Results: Neither age nor age at first sexual intercourse was associated with HPV 16 antibodies. Adjusted ORs for 4-5, 6-10 and >10 versus $0-1$ lifetime sexual partners, were $13 \cdot 1$ (95\% CI $1 \cdot 5-110 \cdot 8), 8 \cdot 2(1 \cdot 0-69 \cdot 6)$ and $10 \cdot 5(1 \cdot 2-94 \cdot 0)$ for HPV 16 seropositivity, respectively; and $2 \cdot 6$ $(0 \cdot 2-27 \cdot 8), 3 \cdot 4(0 \cdot 4-31 \cdot 7)$ and $4 \cdot 1(0 \cdot 4-42 \cdot 8)$ for HPV 16 DNA positivity, respectively.

Conclusion: Seropositivity to HPV 16 capsids is positively associated with the number of sexual partners, suggesting that HPV 16 is predominantly sexually transmitted. The fact that serology had a stronger association with number of sexual partners than viral DNA suggests that seroreactivity is a better measure of lifetime history of HPV infection.

(Genitourin Med 1997;73:131-135)

Keywords: human papilloma virus; DNA; capsids; sexual behaviour

\section{Introduction}

Human papilloma virus (HPV) is considered to be the major causal factor for dysplasia and cancer of the uterine cervix. ${ }^{1-8} \mathrm{HPV}$ is sexually transmissible. However, the quantitative importance of non-sexual transmission is unclear. DNA of the genital types of HPV has been reported to be present in the oral mucosa of children and corresponding serum antibodies to be common in children. ${ }^{910}$ Several early studies also failed to find a clear association between sexual activity and detection of genital HPV infection. ${ }^{11-14}$ These studies did not use reliable PCR techniques for the detection of HPV DNA, and the lack of association may have been due to misclassification of HPV status. More recent studies, using validated PCR, have shown a strong association with the number of sexual partners. ${ }^{15-18}$

The need to evaluate the importance of sexual activity for the transmission of oncogenic HPV infections is obvious. To obtain results which are generally applicable, population based studies in women with age corresponding to the ages where high grade dysplasia appears is important. The choice of marker of HPV 16 infection is crucial in relation to whether present infection or lifetime exposure is the question under study. Despite very sensitive techniques for the detection of HPV DNA, a single test for detecting HPV DNA in the cervix may be a false negative owing to sampling errors. Another diagnostic problem is that HPV infections seem to be transient in the majority of cases. ${ }^{19} 20$ Thus no information on past infections is obtained if HPV DNA is no longer present in the tissue. Obtaining reli- able data on sexual behaviour is also difficult. A potentially useful way of estimating lifetime exposure to HPV is to study serum antibody responses.

The aim of our study was to examine the association between sexual behaviour and presence of antibodies against HPV 16 capsids and to compare that with the estimated association between sexual behaviour and detection of HPV DNA in cytological specimens from the uterine cervix, in a representative sample of the female population in Oslo, Norway.

\section{Materials and methods}

STUDY POPULATION

In 1991-2 a population based case-control study was conducted in Oslo, Norway to estimate the association between cervical intraepithelial neoplasia (CIN) II-III and HPV as detected by PCR. ${ }^{6}$ Women of Norwegian descent, aged 20 to 44 years, and presently living in Oslo were invited. Exclusion criteria were pregnancy, menopause, previous treatment for dysplasia or a history of other gynaecological malignancies. The control group was randomly selected from the Central Population Register and group matched for age to a case series. ${ }^{6}$ Of the traceable women who fulfilled the inclusion criteria, $71.8 \%$ were willing to participate. All participants had a cervical smear and a serum sample taken at study entry. Only women with both cytological and serological diagnoses were included in this study.

The 234 women, aged 20-44 years (mean $32 \cdot 8$ years, median 32 ), included women with 
normal cytology $(n=208)$, women with HPV signs in cytology $(n=20)$ and women in whom CIN II-III/cancer was diagnosed at study entry $(n=6)$.

SPECIMEN COLLECTION, CYTOLOGICAL EXAMINATION AND DETECTION OF HPV DNA Serum samples and cervical specimens were obtained according to a standardised protocol at the same visit as the interview took place. Endocervical brushes were used to prepare a smear and were then placed in phosphate buffered saline (PBS) until preparation in the laboratory. Smears were stained by the Papanicolaou method and examined by a trained cytopathologist not informed about laboratory findings or interview data (TS). $\beta$ Globin positive cytological specimens were analysed with polymerase chain reaction (PCR) using general nested primer pairs detecting HPV types $6,11,16,18,31$ and 33 as well as a number of unknown HPV types. ${ }^{21}$ The preparation of cytological specimens and the typing of the nested positive samples have been described elsewhere. ${ }^{22}$ The pellets for PCR and serum were stored at $-70^{\circ} \mathrm{C}$.

\section{HPV SEROLOGY/ELISA}

Enzyme linked immunosorbent assay (ELISA) methodology, as described elsewhere, ${ }^{23}$ was used to detect antibodies against HPV $16 \mathrm{cap}$ sids in serum samples at a 1:30 dilution. The capsids were obtained from Dr John $T$ Schiller, National Cancer Institute, Bethesda, MD, USA and their preparation and characterisation is described in detail elsewhere. ${ }^{24}$ Antibody levels exceeding a pre-assigned cut off level of $0.100 \mathrm{dOD}$ (difference in optical density) were considered as a positive result.

\section{INTERVIEW DATA/INDEPENDENT VARIABLES}

Data on sexual and reproductive history were obtained through a structured interview carried out by a female physician (AOO). The interview took place at the hospital in connection with the physical examination and the sample collection. An exposure by time matrix was constructed for the sexual history. Data on the number of sexual partners were obtained in two ways, first by asking the simple question about total number of sexual partners, then by asking for number of partners within 5 year intervals visualised in the exposure by time matrix containing data about major steady relationships and reproductive events. If the index person reported fewer than 10 sexual partners, it was reported with an exact number. If more, it was reported as "about 10 to 15 ", "about 15 to 20 " and "more than 20 ".

\section{STATISTICAL ANALYSES}

The "outlying" very high antibody levels were considered as biologically valid and were not excluded. Because of skewed, non-normal distribution of data, a non-parametric test (Kruskal-Wallis) was applied when the serological data were treated as continuous variables. To describe the distribution of observations, percentiles $(50,75,90)$ were used.
For bivariate and multivariate analyses, the dependent variable (serum antibody response) was made dichotomous by using a preassigned cut off at $0 \cdot 100 \mathrm{dOD}$ and an alternative cut off at $0.300 \mathrm{dOD}$. For bivariate analyses, $\chi^{2}$ tests were applied. Stratified analyses were performed employing EPI INFO, Version $6 .{ }^{25}$ The multivariate logistic regression analyses were performed employing SPSS for Windows, release $6 \cdot 0,{ }^{26}$ and the strength of associations were expressed as odds ratios (OR).

The multivariate analyses were restricted to subjects with complete data on both serology and HPV DNA $(n=222)$.

\section{ETHICS}

The study was approved by the regional committee for medical research ethics. Informed, written consent was obtained from all participants.

\section{Results}

Treated as a continuous variable, seroreactivity against HPV 16 capsids was marginally higher in the youngest women (20-24 years) and lower in ages 25-29 years, compared with women 30 years or older (Kruskal-Wallis, $p=$ $0.05)$. The seroreactivity was not associated with age at first sexual intercourse (table 1). Women with normal cervical cytology tended to have lower levels of antibodies than women with HPV morphology or cervical dysplasia (Kruskal-Wallis, $p=0.06$ ). Subjects with fewer than four partners had lower levels of antibodies (Kruskal-Wallis, $\mathrm{p}<0.01$ ) (table 1). Treated as a dichotomous variable, 39 women $(16.7 \%)$ had serum immune response above the pre-assigned cut off level at $0 \cdot 100$ dOD.

The proportion of women with antibody response above $0 \cdot 100$ was significantly lower in the category with normal cytology than in the categories of cytological features of HPV or $\operatorname{CIN}\left(\chi^{2} 6 \cdot 8, p=0.03\right)$. Age at first sexual intercourse did not influence the seropositivity in the pooled sample or in the age groups; 20-29, 30-34 and 35-44, separately (data not ô shown). Comparing women who reported four or more lifetime sexual partners with women with 0-3 partners, the ORs for seropositivity in the three age strata were $5.9(0.7-129), 5 \cdot 1$ $(0.6-113)$ and $3.6(0 \cdot 7-26)$, respectively. The crude OR for all strata was $4 \cdot 7$, whereas the Mantel-Haenszel weighted OR was 4.6 (1.5-15.9). Hence, interaction or confounding from age on the association between the number of sexual partners and seropositivity against HPV 16 was not observed. In the pooled sample, a dose-response relation between the number of sexual partners and antibody response above $0 \cdot 100$ was found $\left(\chi^{2}=6 \cdot 8,1 \mathrm{DF}, \mathrm{p}\right.$ for trend $\left.=0.009\right)$.

Age at first cohabitation, a measure of the start of a more regular sexual life, was not related to the lifetime number of sexual partners and was not further analysed in the models.

Three of 17 women $(17 \cdot 6 \%)$ with HPV type 
Table 1 Median, 75 and 90 percentiles for HPV 16 capsid antibodies and distribution of positives (cut off level of 100 dOD $\times 1000$ ) according to cytological diagnosis, age, age at first sexual intercourse, number of sexual partners and presence of HPV DNA in uterine cervix in a population based sample of women

\begin{tabular}{|c|c|c|c|c|c|c|c|c|}
\hline & \multirow[b]{2}{*}{$N$} & \multicolumn{4}{|c|}{ HPV 16 capsid antibodies $(d O D \times 1000)$} & \multicolumn{3}{|c|}{ HPV 16 capsid seropositivity } \\
\hline & & Median & 75 & 90 & Kruskal-Wallis $p$ value* & Pos & $\%$ & $\chi^{2} p$ value \\
\hline ALL & 234 & $0 \cdot 0$ & $5 \cdot 3$ & $184 \cdot 0$ & \multirow{5}{*}{0.06} & 39 & $16 \cdot 7$ & \multirow{5}{*}{0.03} \\
\hline Cytological diagnosis & & & & & & & & \\
\hline Normal & 208 & 0.0 & 0.0 & $153 \cdot 7$ & & 30 & $14 \cdot 4$ & \\
\hline $\begin{array}{l}\mathrm{HPV} \\
\mathrm{CIN} / \text { cancer }\end{array}$ & & 0.0 & $155 \cdot 8$ & $396 \cdot 1$ & & 7 & $35 \cdot 0$ & \\
\hline CIN/cancer & 6 & $1 \cdot 0$ & 509.5 & & & 2 & $33 \cdot 3$ & \\
\hline Age (years) & & & & & \multirow[t]{6}{*}{0.05} & & & \multirow[t]{6}{*}{$0 \cdot 13$} \\
\hline $20-24$ & 15 & $0 \cdot 0$ & $124 \cdot 0$ & $412 \cdot 0$ & & 5 & $33 \cdot 3$ & \\
\hline $25-29$ & 69 & 0.0 & 0.0 & 79.0 & & 6 & $8 \cdot 7$ & \\
\hline $30-34$ & 71 & $0 \cdot 0$ & $25 \cdot 0$ & $271 \cdot 2$ & & 15 & $21 \cdot 1$ & \\
\hline $35-39$ & 50 & $0 \cdot 0$ & $10 \cdot 5$ & $181 \cdot 8$ & & 8 & $16 \cdot 0$ & \\
\hline $40-44$ & 29 & $0 \cdot 0$ & $17 \cdot 0$ & $264 \cdot 0$ & & 5 & $17 \cdot 2$ & \\
\hline Age first intercourse & & & & & \multirow[t]{4}{*}{0.99} & & & \multirow[t]{4}{*}{0.96} \\
\hline$<17$ & 78 & $0 \cdot 0$ & $14 \cdot 0$ & $163 \cdot 4$ & & 13 & $16 \cdot 7$ & \\
\hline $17-18$ & 76 & 0.0 & 1.5 & $176 \cdot 3$ & & 12 & $15 \cdot 8$ & \\
\hline $\begin{array}{ll}19+ \\
\end{array}$ & 80 & $0 \cdot 0$ & $3 \cdot 0$ & $249 \cdot 2$ & & 14 & $17 \cdot 5$ & \\
\hline No of sexual partners & & & & & \multirow{6}{*}{$<0.01$} & & & \multirow{6}{*}{$<0.01 \dagger$} \\
\hline $0-1 \neq$ & 32 & $0 \cdot 0$ & 0.0 & 0.0 & & 1 & $3 \cdot 1$ & \\
\hline $2-3$ & 40 & $0 \cdot 0$ & $0 \cdot 0$ & $71 \cdot 2$ & & 3 & $\begin{array}{r}7 \cdot 5 \\
26.5\end{array}$ & \\
\hline $4-5$ & 45 & $0 \cdot 0$ & 110.5 & $268 \cdot 4$ & & 12 & $26 \cdot 7$ & \\
\hline 6-10 & 69 & $0 \cdot 0$ & 10.5 & $173 \cdot 0$ & & 11 & $15 \cdot 9$ & \\
\hline$>10$ & 48 & 0.0 & 111.0 & 408.0 & & 12 & $25 \cdot 0$ & \\
\hline HPV DNAS & & & & & \multirow[t]{4}{*}{0.99} & & & \multirow[t]{4}{*}{0.96} \\
\hline Negative & & $0 \cdot 0$ & $7 \cdot 8$ & $178 \cdot 5$ & & 30 & $16 \cdot 3$ & \\
\hline 16 & 17 & 0.0 & 24.5 & $467 \cdot 0$ & & 3 & $17 \cdot 6$ & \\
\hline Others & 21 & 0.0 & 38.5 & 160.8 & & 3 & $14 \cdot 3$ & \\
\hline
\end{tabular}

${ }^{\star}$ Kruskal-Wallis test (corrected for ties) for the continuous variable.

†Mantel-Haenszel test for linear association.

$\ddagger$ Two women with zero number of sexual partners.

$\oint N=222$. "Other" includes HPV type $6 / 11,18,31,33$, and unknown types.

16 DNA had a serum antibody level above $0 \cdot 100 \mathrm{dOD}$. Of the 205 subjects who were either HPV DNA negative or positive for other HPV types, $33(16 \cdot 1 \%)$ were seropositive.

In multivariate logistic regression analysis, age, age at first sexual intercourse and number of sexual partners were included into the same model (table 2). With the age group $30-34$ as reference, no significant differences in serum immune response between the age groups were found (table 2, model 1). Women with early sexual debut showed no increased risk for being seropositive. The adjusted OR for seropositivity against HPV $16(>0 \cdot 100 \mathrm{dOD})$ was $13 \cdot 1(95 \%$ CI $1 \cdot 5-110 \cdot 8)$ for subjects reporting 4-5 lifetime sexual partners, $8 \cdot 2$ (95\% CI 1.0-69.6) for those reporting 6-10 partners and 10.5 (95\% CI 1.2-94.0) for subjects reporting more than 10 partners as compared with those with 0-1 partners (table 2, model 1). When HPV 16 DNA was studied in one group and the subjects who were positive for other types were categorised together with the HPV negative subjects, neither an association with age nor with sexual history was found (table 2, model 2). For HPV DNA, all types combined (table 2, model 3), a marginally significant association with younger age (20-24 and 25-29) was found. An association with HPV DNA (any types) was seen when the reported number of sexual partners exceeded five but was only significant for more than 10 partners; OR $7 \cdot 8(95 \% \mathrm{CI} 1 \cdot 5-41 \cdot 7)$. A major contribution came from the few women positive for HPV type 6/11 and 18, of whom three of four and two of three reported 10 or more partners, respectively.

\section{Discussion}

We have found that antibodies against HPV 16 capsids is a strong marker for past sexual

Table 2 Adjusted odds ratio for the association between age, age at first sexual intercourse, number of sexual partners and HPV as measured by antibodies to HPV 16 capsids or by HPV DNA in uterine cervix as detected by PCR, in 222 women

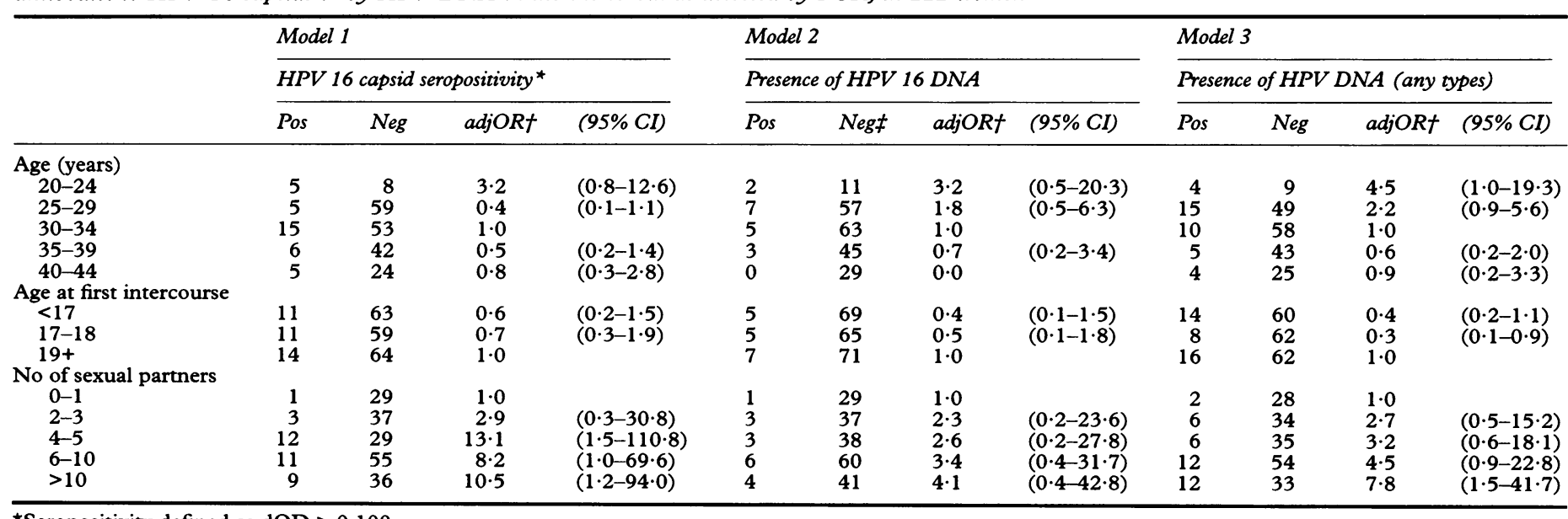

^Seropositivity defined as dOD $>0 \cdot 100$.

tAdjusted for age, age at first sexual intercourse and number of sexual partners.

¥Includes HPV DNA negatives and positives for any other types than 16 . 
activity (number of sexual partners), indicating a primarily sexual route of HPV transmission. This is in line with the results from a Swedish study of female adolescent students. Andersson-Ellstrom et al did not find HPV DNA in cervix ${ }^{27}$ or serum antibodies against HPV 16 capsids $^{28}$ among virgins. In another study of 130 vaginal samples from Swedish virginal women, two were HPV 6 DNA positive whereas no HPV 16 DNA was found. ${ }^{29}$ Also an Australian study found no HPV DNA positives in analyses of tampon specimens from virgins. ${ }^{30}$ However, there are also contradictory findings reported; no significant difference was found in the prevalence of vulvar HPV DNA in virginal and sexually active Chinese women. ${ }^{31}$

In the large clinic based study of randomly selected cytologically normal women, a doseresponse relation between number of sexual partners and HPV prevalence was reported. The adjusted prevalence was $16.9 \%$ higher in women reporting 10 or more partners compared with women reporting one life-time sexual partner. ${ }^{15}$ We found no uniformly increasing trend, but with more than three partners the seroprevalence reached a plateau. An association of seroprevalence with number of partners, that levelled at a high number of partners was also found in another study, although a younger population was studied and the plateau was reached at a higher number of partners (6-10). ${ }^{32}$ The plateau phenomenon was also observed in a study based on HPV DNA detection. ${ }^{33}$ In this a threshold effect between monogamous and non-monogamous women was found, probably because the likelihood of exposure to HPV with each sexual partner was increased in this high prevalence population. ${ }^{33}$ The phenomenon may also reflect a "saturation", that is, a point where most women have been exposed to HPV is reached. We found a trend towards an increasing prevalence of HPV DNA with increasing number of lifetime sexual partners. A significant association was observed only for women reporting more than 10 partners. Possibly, past HPV infections may have been eliminated by the time of sample collection and women with many partners may carry HPV DNA because of more recent (re)infections.

In the studies reporting a strong association between HPV DNA and number of partners, ${ }^{16-18}$ the mean age has been markedly lower, pointing to a more recent sexual history with HPV DNA still present. Only one of these cross sectional studies has been carried out in a group that is representative for the general population of young females. ${ }^{18}$

Selection bias is a minor problem in our study because sampling was based on personal identification numbers in the comprehensive and complete Norwegian population register. Furthermore, there were relatively few (98 of 348) who did not respond or who refused to participate, and these women did not differ from the attendees with respect to age or marital status (data not shown). None of the attendees refused to answer questions or to give biological specimens. To obtain reliable data on sexual history may be difficult and may to some extent explain discrepant findings in the literature. We emphasised a confident setting, the consultation including a personal interview by a female practitioner lasting about 45 to 60 minutes. However, the possible bias from interviewer effect cannot be assessed since all interviews were made by one interviewer. Efforts were made to avoid recall bias by obtaining sexual and reproductive history chronologically and in parallel. Since an exposure by time matrix was subsequently filled in, ? the respondent also had the opportunity to $\overrightarrow{\overline{\vec{S}}}$ revise answers. All analyses for the detection of $\frac{\sigma}{\sigma}$ HPV DNA and HPV 16 antibodies were performed with the analysing laboratory blinded to the identity of the samples.

A variety of HPV serological assays that are associated with clinical disease and cancer exist. $^{3435}$ However, serology based on HPV capsids is the assay that shows best agreement $\vec{\omega}$ with detection of HPV DNA in the uterine cervix of women with asymptomatic HPV 16 infections or cervical intraepithelial neoplasia $\omega$ (CIN). ${ }^{34}$ Among $54 \mathrm{HPV} 16$ DNA positive women, $59 \%$ had IgG to HPV 16 capsids, whereas only two of $31 \mathrm{HPV}$ DNA negative 옥 women showed seropositivity. ${ }^{24} \mathrm{~A}$ high speci- $\rightarrow$ ficity is also indicated by the fact that no vir- $\frac{T}{0}$ gins were seropositive and by seroconversions following the detection of HPV DNA. ${ }^{28}$ Cross $\vec{\bullet}$ reactivity to other HPV types appears to be : limited. ${ }^{36} 37$

The poor agreement between serology and PCR in this study ${ }^{38}$ has also been reported by Wideroff et al, who found $17 \%$ of HPV $16 \frac{2}{\varnothing}$ DNA negative subjects to be seropositive. ${ }^{37} \stackrel{\square}{\square}$ Among women who were found to be HPV 16 을 DNA positive on only one occasion, either at enrolment or at follow up, $22 \%$ were seropositive which corresponds to the $17 \cdot 6 \%$ reported in the present study. It is probable that serology and PCR have different sensitivities for measuring past versus present exposure and $\dot{\delta}$ transient versus persistent infection to HPV. This assumption is strengthened by the find- 0 ing of increased seropositivity, to $83 \%$, for subjects who tested HPV 16 DNA positive at two separate occasions. ${ }^{37}$ Our cross sectional o study design with one single cervical sample cannot assess the nature and course of HPV infection. In longitudinal studies it has been shown that seroconversions may occur relatively concomitantly with detection of new HPV DNA. ${ }^{2836}$ On the other hand, it seems that not all HPV infected individuals will 0 develop antibodies. No seroconversion was observed in one of six girls who acquired cervical HPV 16 DNA during follow up. ${ }^{28}$ In another study, 22 of $54 \mathrm{HPV} 16 \mathrm{DNA}$ positives were HPV 16 L1 ELISA negative. ${ }^{24}$

In two case-control studies, both reporting no significant relation between the number of sexual partners and serum antibodies to HPV, the serological assays used measured antibody response associated with neoplasia, but not with infection. ${ }^{39} 40$ However, seropositivity against HPV 16 and/or HPV 33 capsids is indeed associated with infection and is also associated with the number of sexual partners 
and with sexual intercourse before the age of $17 .^{28}$

The strong association of seropositivity with the number of sexual partners observed in this study suggests that seropositivity reflecting the past history of exposure to HPV is common. Transient HPV antibody response, that is, loss of seropositivity after clearance of the viral DNA has, however, been described. ${ }^{28} 36$

In conclusion, the association between serum antibody response to HPV 16 and lifetime number of sexual partners is evidence for a principally sexually transmitted route of HPV 16. Serum immune responses to HPV capsids appears to be a better marker for lifetime HPV exposure than HPV DNA measurements.

We are grateful to the study participants. We thank cytopathologist Dr Torill Sauer for her careful work and collaboration and Dr Ivar Ørstavik for his useful advice and support. We also thank the technical staff at the laboratories involved. This study was supported by the Research Council of Norway, the Norwegian and the Swedish Cancer Societies.

Dr A O Olsen is in receipt of a research fellowship from the Dr A O Olsen is in receipt
Research Council of Norway.

1 Eluf Neto J, Booth M, Munoz N, Bosch FX, Meijer CJ, Walboomers JM. Human papillomavirus and invasive cervical cancer in Brazil. Br f Cancer 1994;69:114-9.

2 Bosch FX, Munoz N, de Sanjose S, Navarro C, Moreo P, Ascunce N, et al. Human papillomavirus and cervical intraepithelial neoplasia grade III/carcinoma in situ: a case-control study in Spain and Colombia. Cancer Epidemiol Biomarkers Prev 1993;2:415-22.

3 Munoz N, Bosch FX, de Sanjose S, Tafur L, Izarzugaza I, Gili M, et al. The causal link between human papillomavirus and invasive cervical cancer: a population-based case-control study in Colombia and Spain. Int $\mathcal{f}$ Cancer 1992;52:743-9.

4 Koutsky LA, Holmes KK, Critchlow CW, Stevens CE, Paavonen J, Beckmann AM, et al. A cohort study of the risk of cervical intraepithelial neoplasia grade 2 or 3 in
relation to papillomavirus infection. N Engl $f$ Med 1992;327:1272-8.

5 Schiffman MH, Bauer HM, Hoover RN, Glass AG, Cadell $\mathrm{DM}$, Rush BB, et al. Epidemiologic evidence showing that human papillomavirus infection causes most cervical that human papillomavirus infection causes most cervical intraepithe

6 Olsen AO, Gjoen K, Sauer T, Orstavik I, Naess O, Kierulf $\mathrm{K}$, et al. Human papillomavirus and cervical intraepithelial neoplasia grade II-III: a population-based case-control study. Int $\mathcal{f}$ Cancer 1995;61:312-5.

7 Morrison EA, Ho GY, Vermund SH, Goldberg GL Kadish AS, Kelley KF, et al. Human papillomavirus infection and other risk factors for cervical neoplasia: case-control study. Int $\mathcal{F}$ Cancer 1991;49:6-13.

8 Becker TM, Wheeler CM, McGough NS, Parmenter CA, Jordan SW, Stidley CA, et al. Sexually transmitted diseases and other risk factors for cervical dysplasia among southwestern Hispanic and non-Hispanic white women. southwestern Hispanic and
$7 A M A$ 1994;271:1181-8.

9 Jenison SA, Yu XP, Valentine JM, Koutsky LA, Christiansen AE, Beckmann AM, et al. Evidence of prevalent genital-type human papillomavirus infections in adults and children. $\mathcal{F}$ Infect Dis 1990;162:60-9.

10 Jochmus Kudielka I, Schneider A, Braun R, Kimmig R, Koldovsky U, Schneweis KE, et al. Antibodies against the human papillomavirus type 16 early proteins in human sera: correlation of anti-E7 reactivity with cervical cancer. $\Im$ Natl Cancer Inst 1989;81:1698-704.

11 Reeves WC, Brinton LA, Garcia M, Brenes MM, Herrero $\mathbf{R}$, Gaitan $\mathrm{E}$, et al. Human papillomavirus infection and cervical cancer in Latin America. $N$ Engl $₹$ Med 1989; 320:1437-41.

12 Kiviat NB, Koutsky LA, Paavonen JA, Galloway DA, Critchlow CW, Beckmann AM, et al. Prevalence of genital papillomavirus infection among women attending college student health clinic or a sexually transmitted disease clinic. F Infect Dis 1989;159:293-302.

13 Kjaer SK, Engholm G, Teisen C, Haugaard BJ, Lynge E, Christensen RB, et al. Risk factors for cervical human papillomavirus and herpes simplex virus infections in Ereenland and Denmark: a population-based study. $A m \mathcal{F}$

14 Villa LL, Franco EL. Epidemiologic correlates of cervical neoplasia and risk of human papillomavirus infection in asymptomatic women in Brazil. $₹$ Natl Cancer Inst 1989 81:332-40.

15 Bauer HM, Hildesheim A, Schiffman MH, Glass AG, Rush BB, Scott DR, et al. Determinants of genital human papillomavirus infection in low-risk women in Portland, Oregon. Sex Transm Dis 1993;20:274-8.

16 Ley C, Bauer HM, Reingold A, Schiffman MH, Chambers
JC, Tashiro CJ, et al. Determinants of genital human papillomavirus infection in young women. 7 Natl Cancer Inst 1991;83:997-1003.

17 Moscicki AB, Palefsky J, Gonzales J, Schoolnik GK. Human papillomavirus infection in sexually active adolescent females: prevalence and risk factors. Pediatr Re 1990;28:507-13.

18 Karlsson $R$, Jonsson $M$, Edlund $K$, Evander $M$, Gustavsson A, Boden E, et al. Lifetime number of partners as the only independent risk factor for human papillomavirus infection: a population-based study. Sex Transm Dis 1995;22:119-27.

19 Evander $M$, Edlund $K$, Gustavsson A, Jonsson $M$, Karlsson R, Rylander E, et al. Human papillomavirus infection is transient in young women: a populationbased cohort study. $\mathcal{F}$ Infect Dis 1995;171:1026-30.

20 Hildesheim A, Schiffman MH, Gravitt PE, Glass AG, Greer CE, Zhang T, et al. Persistence of type-specific human papillomavirus infection among cytologically normal women. F Infect Dis 1994;169:235-40.

21 Williamson AL, Rybicki EP. Detection of genital human papillomaviruses by polymerase chain reaction amplification with degenerate nested primers. F Med Virol 1991; 33:165-71.

22 Gjoen K, Siebke JC, Flikke M, Hager R, Ertzeid G, Halso $A$, et al. Genital human papilloma virus infection in Oslo studied by dot blot DNA hybridization and the polymerase chain reaction. $f$ Med Virol 1991;34 159-64.

23 Dillner J, Lenner $P$, Lehtinen $M$, Eklund C, Heino $P$, Wiklund $F$, et al. A population-based seroepidemiological study of cervical cancer. Cancer Res 1994;54:134-41.

24 Kirnbauer R, Hubbert NL, Wheeler CM, Becker TM, Lowy DR, Schiller JT. A virus-like particle enzymelinked immunosorbent assay detects serum antibodies in majority of women infected with human papillomavirus type 16. $\mathcal{f}$ Natl Cancer Inst 1994;86:494-9.

25 Dean AG, Dean JA, Burton AH, Dicker RC. Epi Info, Version 6: a word processing, database, and statistics program for epidemiology on microcomputers. Atlanta Grogram for epia, USA: Centers for Disease Control and Prevention; 1994.

26 Norusis MJ. SPSS for windows: Advanced Statistics. 6.0. Chicago, USA: SPSS INC. 1993.

27 Andersson-Ellstrom A, Dillner J, Hagmar B, Schiller J, Forssman L. No serological evidence for non-sexual spread of HPV16 [letter]. Lancet 1994;344:1435.

28 Andersson-Ellstrom A, Dillner J, Hagmar B, Schiller J Sapp M, Forssman L, et al. Comparison of development of serum antibodies to HPV16 and HPV 33 and acquisition of cervical HPV DNA among sexually experienced and virginal young girls. A longitudinal cohort study. Sex Transm Dis 1996;23:234-8.

29 Rylander E, Ruusuvaara L, Almstromer MW, Evander M, Wadell $G$. The absence of vaginal human papillomavirus 16 DNA in women who have not experienced sexual 16 DNA in women who have not experier
intercourse. Obstet Gynecol 1994;83:735-7.

30 Fairley CK, Chen S, Tabrizi SN, Leeton K, Quinn MA Garland SM. The absence of genital human papillomavirus DNA in virginal women. Int $\mathcal{F}$ STD AIDS 1992; 3:414-7.

31 Pao CC, Tsai PL, Chang YL, Hsieh TT, Jin JY. Possible non-sexual transmission of genital human papillomavirus infections in young women. Eur $\mathcal{F}$ Clin Microbiol Infect Dis 1993;12:221-2.

32 Dillner J, Kallings I, Brihmer C, Sikstrøm B, Koskela P Lehtinen $M$, et al. Seropositivity to human papillomavirus types 16,18 , or 33 capsids and to Chlamydia trachomatis are markers of sexual behavior. $\mathcal{F}$ Infect Dis 1996 173:1394-8.

33 Hildesheim A, Gravitt P, Schiffman MH, Kurman RJ, Barnes W, Jones S, et al. Determinants of genital human papillomavirus infection in low-income women in Washington, DC. Sex Transm Dis 1993;20:279-85.

34 Dillner J. Serology of human papillomavirus. Cancer fournal 1995;8:264-9.

35 Dillner J. Antibody responses to defined HPV epitopes in cervical neoplasia. Papillomavirus Report 1994;5:35-41.

36 Wikstrom A, van Doornum GJ, Quint WG, Schiller JT, Dillner J. Identification of human papillomavirus seroconversions. I Gen Virol 1995;76:529-39.

37 Wideroff L, Schiffman MH, Nonnenmacher B, Hubbert N, Kirnbauer R, Greer CE, et al. Evaluation of seroreactivity to human papillomavirus type 16 virus-like particles in an incident case-control study of cervical neoplasia. $\mathcal{F}$ Infect Dis 1995;172:1425-30.

38 Olsen AO, Dillner J, Gjoen K, Sauer T, Ørstavik I, Magnus P. A population-based case-control study of human papillomavirus-type-16 seropositivity and incident highgrade dysplasia of the uterine cervix. Int $\mathcal{f}$ Cancer 1996;68:415-9.

39 Sun Y, Eluf Neto J, Bosch FX, Munoz N, Booth $M$ Walboomers JM, et al. Human papillomavirus-related serological markers of invasive cervical carcinoma in Brazil. Cancer Epidemiol Biomarkers Prev 1994;3:341-7.

40 Mann VM, de Lao SL, Brenes M, Brinton LA, Rawls JA, Green M, et al. Occurrence of IgA and IgG antibodies to select peptides representing human papillomavirus type 16 among cervical cancer cases and controls. Cancer Res
$1990 ; 50: 7815-9$. 